\title{
CYTOPLASMIC MALE-STERILITY IN OIL-SEED RAPE
}

\author{
K. F. THOMPSON
}

Plant Breeding Institute, Trumpington, Cambridge

Received 6.iv.72

\section{INTRODUCTION}

Cytoplasmic male-sterility has not been reported previously in oil-seed rape (Brassica napus). In this paper, evidence for cytoplasmic male-sterility is based on the occurrence of pollen-sterility in the $\mathrm{F}_{2}$ generation from hybrids, in which the Polish spring variety, Bronowski, was the male parent and on its absence when Bronowski was the female parent.

\section{Material AND methods}

The origin and description of lines of oil-seed rape, referred to in this paper, are given in table 1 .

TABLE 1

Origin of oil-seed rape lines

\begin{tabular}{|c|c|c|}
\hline Rape type & Line No. & Origin and description \\
\hline Winter & $\begin{array}{l}\text { R.D. } 49 \\
\text { R.D. } 53\end{array}$ & HDL's ${ }^{1}$ from Victor ${ }^{2}$ \\
\hline Spring & $\begin{array}{l}\text { R } 239 / 2 / 10 \\
\text { R.D. } 495 \\
\text { R } 238 / 1 \\
\text { R.D. } 15 \\
\text { R.D. } 6 \\
\text { Bronowski }\end{array}$ & $\begin{array}{l}\text { Inbred from Rigo }{ }^{2} \text {; homozygous for } G^{3} \\
\text { HDL from Rigo; partially male-sterile } \\
\text { Inbred from Nilla } \\
\text { HDL from Nilla; partially male-sterile } \\
\text { HDL from Target } \\
\text { Seed multiplication station, Poland } \\
\text { Sed }\end{array}$ \\
\hline \multicolumn{3}{|c|}{$\begin{array}{l}1 \text { Homozygous diploid line obtained by colchicine treatment of } \\
\text { oloid. } \\
2 \text { From Swedish Seed Association, Svalof, Sweden. } \\
3 \text { Incompletely dominant allele for glossy leaves and stems. } \\
4 \text { From Professor B. R. Stefansson, University of Manitoba, } \\
\text { nada. } \\
5 \text { From Dr R. K. Downey, Department of Agriculture, Saskatoon, } \\
\text { nada. }\end{array}$} \\
\hline
\end{tabular}

The following crosses were made and the $F_{1}$ and $F_{1}$ generations grown:

\begin{tabular}{|c|c|c|c|}
\hline RD 49 & 우 & $\times$ & Bronowski 2 \\
\hline RD 53 & 우 & $x$ & Bronowski 1 \\
\hline R 239/2/10 & 우 & $x$ & Bronowski 2 \\
\hline R 238/1 & 우 & $x$ & Bronowski 1 \\
\hline $\mathrm{RD} 6$ & 우 & $x$ & Bronowski l \\
\hline Bronowski 1 & 우 & $x$ & RD 495 \\
\hline
\end{tabular}

One backcross to Bronowski was grown:

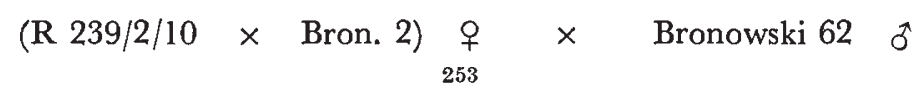


The $F_{1}$ generation plants were grown in the glasshouse and selfed seed obtained by bagging plants. The $\mathrm{F}_{2}$ and the backcross generations were grown in the field.

\section{Results}

(a) Winter rape $\times$ Bronowski

The $\mathrm{F}_{1}$ of the cross, RD $53 q \times$ Bronowski $1 \hat{\sigma}$, had normal fertility, but the $F_{2}$ segregated for male-sterility. Almost all $F_{2}$ plants survived the mild winter of 1970-71 in the field and were scored for pollen-fertility in May. A high proportion of male-sterile plants in the $F_{2}$ generation could be distinguished easily by their narrow petals and short stamens with little pollen, but the degree of male-sterility was variable, being rarely complete. Occasional plants with very narrow petals and no pollen in the anthers were noted in the field, but even these plants produced some pollen when transferred to the glasshouse. The male-sterile plants are homozygous for a recessive allele designated $r f$; pollen-fertile plants are either $R f R f$ or $R f r f$. A few plants had fairly broad petals which were slightly folded while the anthers had some pollen. These plants were classified as pollen-fertile in figures entered in the first row of table 2 ; the $\chi^{2}$ value showed a poor fit to a $3: 1$ segregation for pollen-fertile: pollen-sterile plants. For the results given in the second row of table 2, five slightly pollen-sterile plants were included in

TABLE 2

Segregation for male-sterility in $\mathrm{F}_{2}$ ㅇ R.D. $53 \times$ Bronowski $1 \sigma^{*}$

$\begin{array}{ccccc}\text { Pollen } \quad \text { Fertile } & \text { Sterile } & \begin{array}{c}\text { Expected } \\ \text { ratios }\end{array} & \chi^{2} & \text { Probability } \\ R f R f+R f r f & r f r f & & & \\ 339 & 87 & 3: 1 & 4.444 & 0.05-0.02 \\ 94 & 28 * & 3: 1 & 0.027 & 0.80-0.90 \\ & \text { * Includes } 5 \text { partially male-sterile plants. }\end{array}$

the male-sterile group; there is a good fit to a $3: 1$ segregation. The results suggest that segregation of alleles at a single locus determine pollen-fertility or sterility and that sterility results from the homozygous recessive condition, but the expression of male-sterility is modified by other factors.

A similar segregation for pollen-sterile plants occurred in the $F_{2}$ generation from the cross, RD $49 q \times$ Bronowski $2 \hat{\sigma}$, but plants were not scored.

\section{(b) Spring rape $\times$ Bronowski}

The $\mathrm{F}_{1}$ of the cross, $\mathrm{R} 239 / 2 / 10 \times$ Bronowski 2 , had normal fertility and displayed the phenotype resulting from the presence of an incompletely dominant allele, $G$, causing glossy leaves, derived from the $\mathrm{R}$ 239/2/10 parent. The $F_{2}$ segregated for the glossy leaf character and in addition for malesterility as shown in table $3(a)$ and $(b)$. In the first backcross generation derived from the $F_{1}$ and using Bronowski 62 as the recurrent male parent there was again segregation for sterility and fertility as well as for glossy and non-glossy leaves.

Plants, homozygous for the glossy gene, $G G$, had glossy leaves and stems in the field and could be distinguished from the heterozygote, $G g$, which had 
less glossy leaves and glaucous stems. A marked deficiency in the number of homozygous $G G$ plants occurred in the $\mathrm{F}_{2}$ generation, but a good $1: 1$ segregation for heterozygous glossy and non-glossy plants was found in the first backcross generation, in which the non-glossy line, Bronowski 62 was the male parent (table $3(a)$ ). As the proportion of $G g$ to $g g$ plants in the $\mathrm{F}_{2}$ generation gave a good fit to a $2: 1$ segregation, the shortage of $G G$ plants is probably caused by poor survival after fertilisation of the $G G$ embryos.

In both the $\mathrm{F}_{2}$ and first backcross generation to Bronowski there was a strong association of glossy leaves with male-fertility and also of non-glossy

TABLE 3

Segregation for male-sterility and glossy leaves in $\mathrm{F}_{2} R 239 / 2 / 10 \times$ Bronoteski $2 \widehat{\sigma}$ and in the first backcross ( $R$ 239/2/10 $\times$ Bron. 2) $\times$ Bron. 620

(a) Segregation for glossy leaves

\begin{tabular}{|c|c|c|c|c|c|c|}
\hline & & No. plants & & & & \\
\hline & $\begin{array}{c}\text { Glossy leaf } \\
\text { and stem } \\
G G\end{array}$ & $\begin{array}{c}\text { Glossy leaf } \\
\text { glaucous stem } \\
G g\end{array}$ & $\begin{array}{l}\text { Waxy } \\
\text { leaf } \\
\text { gg }\end{array}$ & $\begin{array}{c}\text { Expected } \\
\text { ratios }\end{array}$ & $x^{2}$ & $\mathbf{P}$ \\
\hline 2 genera & 31 & 136 & 68 & $1: 2: 1$ & 9.75 & $0.01-0.001$ \\
\hline st backcross & - & 45 & 52 & $1: 1$ & 0.50 & $0.50-0.3$ \\
\hline
\end{tabular}

(b) Segregation for male-sterility

\begin{tabular}{lccccc} 
& \multicolumn{2}{c}{ No. plants } & & \\
Pollen & $\begin{array}{c}\text { Fertile } \\
R f R f+R f \text { if }\end{array}$ & sterile & Ex $r f$ & Expected \\
ratios & $\chi^{2}$ & P \\
F $_{2}$ generation & 167 & 68 & $3: 1$ & 1.94 & $0.2-0.1$ \\
1st backcross & 47 & 50 & $1: 1$ & 0.09 & $0.8-0.7$
\end{tabular}

(c) Segregation for male-sterility and glossy leaves

No. plants

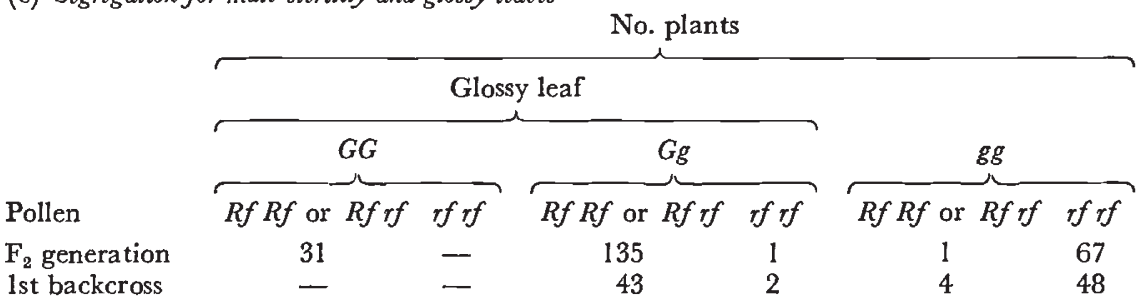

leaves with male-sterility (table $3(c)$ ). Because of this association, the deficiency of homozygous glossy plants in the $\mathrm{F}_{2}$ generation reduced the number of male-fertile plants, so that there was an excess of male-sterile plants for a $3: 1$ segregation (table $3(b)$ ). The alleles for non-glossy leaves, $g$, and for male sterility, $r f$, must be closely linked and the few plants with the constitution $G g, r f r f$ and $g g, R f r f$ were produced by recombination between these two loci. An estimate of the percentage of recombination between $g$ and $r f$ is given in the first backcross, in which six recombinants occurred from 194 gametes. Some recombinants would not be detected in the $\mathrm{F}_{2}$ generation.

The $\mathrm{F}_{1}$ of the crosses, R $238 / 1 \times$ Bronowski 1 s, and R.D. $6 \times$ Bronowski $1{ }^{\star}$ had normal pollen fertility. The $\mathrm{F}_{2}$ generations segregated for pollensterility but the families were not scored.

Bronowski was the female parent in the cross between Bronowski $1 \times$ R.D. 495. Although R.D. 495 was partially male-sterile, the $F_{1}$ had normal 
fertility. The first fifty plants were examined from a three-row bed of the $F_{1}$ generation; all plants were pollen-fertile and no pollen-sterile plants were seen in the remainder of the bed.

These results can be explained on the following hypothesis: Bronowski is homozygous for a recessive allele, $r f$, for pollen-sterility but has a normal or fertile cytoplasm (F) for pollen fertility. The other spring and winter rape lines tested are homozygous for the dominant restorer alleles, $R f, R f$, but have a sterile cytoplasm (S) lacking (F). The male-steriles, which segregated in the $\mathrm{F}_{2}$ and backcross generations, are (S) $r f r f$ as is probably the partially male-sterile, homozygous diploid line, R.D. 495 from Rigo.

\section{Discussion}

This is apparently the first published record of cytoplasmic male-sterility in oil-seed rape (Brassica napus); this is surprising because the spring rape variety, Bronowski, has been widely used in the last few years to introduce genes for low thioglucoside content of the seed meal into other varieties. A possible explanation is that Bronowski has usually been used as the female parent. Krzymanski (1970) reported analyses for segregation of thioglucosides from two crosses with the winter rape varieties, Gulzower Olquell and Borowski, in which Bronowski was the female parent, so segregation for pollen-sterility would not be expected. Kondra and Stefansson (1970) made reciprocal $F_{1}$ hybrids between Bronowski and a selection from Target, but because the two parents were used as females for the first backcrosses, there would be no segregation for pollen-sterile plants. Lein (1970) made reciprocal crosses between Bronowski and an erucic acid-free variety, but it was not stated whether $F_{2}$ seed was grown from both $\mathrm{F}_{1}$ hybrids.

Partially pollen-sterile plants, with narrow or folded petals, were found fairly frequently in the spring rape varieties, Target, Nilla and Rigo at this Institute. From evidence given above, these Canadian and Swedish varieties have a male-sterile cytoplasm (S), which suggests that some of the malesteriles in these varieties have the constitution (S) $r f r f$ and originated as mutations of $R f$ to $r f$.

The application of this type of cytoplasmic male-sterility to produce $F_{1}$ hybrid varieties is unlikely, because pollen-sterility is not complete and is modified by environmental factors. Open pollination of a three-row bed of a partially male-sterile, homozygous diploid line, R.D. 15, in which pollensterility was recessive, gave only 70 per cent. of pollen-fertile hybrids in the following generation.

Partial male-sterility has been noted in the field in autumn-sown selections from the Japanese varieties, Norin No. 16 and Asahi, but these plants were pollen-fertile in the glasshouse. Such environmental variation in pollen-sterility suggests that male-sterility in this material is associated with cytoplasmic control. These Japanese varieties originated from interspecific crosses between Brassica napus as female and B. campestris (Shiga, 1970). A different type of cytoplasmic male-sterility, again associated with narrow petals, was found in the Swedish variety, Panter, which was selected from artificial amphidiploids between $B$. oleracea and $B$. campestris. In this line, open-pollination by surrounding pollen-fertile plants rarely restores pollenfertility and it is also very pollen-sterile in the glasshouse. 


\section{Summary}

1. Partially male-sterile plants occurred in the $F_{2}$ generation from all crosses between both winter and spring rape selections with Bronowski spring rape as the male parent. The sterility was determined by a recessive nuclear gene $r f r f$.

2. In one cross, in which Bronowski was the female parent, no malesterile plants were found in the $\mathrm{F}_{2}$ generation, suggesting that the variety is homozygous for a recessive gene $r f$ for pollen-sterility but has a cytoplasm (F) for pollen-fertility. The other lines examined are homozygous for a dominant pollen-fertility restorer $R f R f$ but have a cytoplasm $(\mathrm{S})$ lacking $\mathrm{F}$; hence the male-steriles found in the $\mathrm{F}_{2}$ generation are (S) $r f r f$.

3. Close linkage was found between the male-sterile gene $r f$ and the gene $g$ for waxy leaves in Bronowski following crosses with plants homozygous or heterozygous for an incompletely dominant gene for glossy leaves, $G$.

\section{REFERENGES}

KONDRA, z. P., AND STEFANSSON, B. R. 1970. Inheritance of the major glucosinolates of rapeseed (Brassica napus) meal. Can. 7. Plant Sci., 50, 643-647.

KRZYMANSKr, J. 1970. Inheritance of thioglucoside content in rapeseed (Brassica napus). Fournées int. sur le Colza Paris, pp. 213-218.

LEIN, K. A. 1970. Methoden zur Bestimmung des Gesamtglucosinolatgehaltes in einzelnen Rapssamen als Grundlage der Selektion von Glucosinolatarmen Raps. Fournées int. sur le Colza Paris, pp. 187-191.

SHIGA, T. 1970. Rape breeding by interspecific crossing between Brassica napus and Brassica campestris in Japan. Japan Agric. Res. Quarterly, 5, 5-10. 